Physical Therapy Journal of Indonesia (PTJI) 2021, Volume 2, Number 2: 50-53

E-ISSN : 2722-6034; P-ISSN : 2722-0125

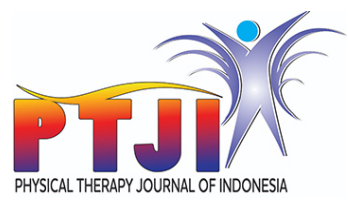

\title{
The Efficacy of Deep Cervical Flexor Training with Feedback Reducing Pain and Disability in Individuals with Work-Related Neck Pain
}

\author{
I Dewa Gede Alit Kamayoga ${ }^{*}$, A. A. I Ayesa Febrinia Adyasputri², \\ I Putu Yudi Pramana Putra', M. Widnyana' ${ }^{1}$, Anak Agung Gede Eka Septian Utama'
}

\begin{abstract}
Introduction: The most common trouble when doing task is work related neck pain. Neck pain can have negative effect on workers related to the resulting work productivity. To conquer this, there is deep cervical flexor training with feedback training to solve that problems. This study aims to find out whether deep cervical flexor training with feedback is powerful in reducing pain and disability the work-related neck pain.

Methods: This study using a literature review by conducting data studies related to deep cervical flexor training with feedback, neck pain, and working. The initial search in 4 databases found a total of

36 articles. After the selection using inclusion and exclusion criteria obtained 28 articles.

Results: Based on some literature, it shows that deep cervical flexor training with feedback aims to activate the deep cervical flexor muscle effectively in reducing pain through the release of endorphins and decreasing pain and changes in muscle function have an effect on reducing disability in work related neck pain.

Conclusion: Providing deep cervical flexor training with feedback is powerful in decreasing the level of pain and disability in workrelated neck pain.
\end{abstract}

'Physiotherapy Department, Faculty of Medicine, Universitas Udayana, Denpasar, Bali ${ }^{2}$ Sports Physiology Department, Faculty of Medicine, Universitas Udayana, Denpasar, Bali

*Corresponding to: I Dewa Gede Alit Kamayoga, Physiotherapy Department, Faculty of Medicine, Udayana University, P.B. Sudirman Street, Denpasar, Bali, Indonesia, 80234; alit kamayoga@unud.ac.id

Received : 2021-10-13 Accepted : 2021-11-24

Published : 2021-12-02

Keywords: Deep cervical flexor training with feedback; Pain and disability; Working, Neck Pain

Cite this Article: Kamayoga, I.D.G.A., Adyasputri, A.A.I.A.F., Putra, I.P.Y.P., Widnyana, M., Utama, A.A.G.E.S. 2021. The Efficacy of Deep Cervical Flexor Training with Feedback Reducing Pain and Disability in Individuals with Work-Related Neck Pain. Physical Therapy Journal of Indonesia 2(2): 50-53. D0l: 10.51559/ptji.v2i2.35

\section{INTRODUCTION}

Musculoskeletal injuries are the problem that often arise when doing a job. Injuries that can occur related to work that requires a worker to carry out work activities in a static position for a long time accompanied by the application of inappropriate body postures and a less ergonomic work environment, causing overexertion. ${ }^{1}$ Neck pain is a musculoskeletal injury that often occurs in the population. The prevalence of neck pain has a fairly high range of about $70 \%$ in the general population, including workers. ${ }^{2}$

Workers who do a job that is monotonous and repetitive for a long time unconsciously have caused microtrauma in body tissues. ${ }^{2}$ Occasionally, workers consider the injury that arises is not a problem that is considered a serious problem. Neck pain can have negative effect on workers related to the resulting work productivity. Furthermore, the result of workrelated neck pain can interfere with daily activities. ${ }^{3}$ The most frequent occupations to experience the occurrence of work-related neck pain in the current era with the more widespread use of technology are office workers who use computers, and teachers in situations with COVID-19, as well as tailor. ${ }^{4}$ Several studies have shown that work performed in a static position for long periods of time is closely related to the occurrence of problems in the neck and upper extremities region. Improper work postures for a long period of time will lead to an adaptation process to the posture position. ${ }^{5}$ Posture that has been adapted will cause stress to the tissues to maintain a normal body position. ${ }^{6}$

Improper posture causes the neck to be in a flexed position which is consistently one of the contributors to neck pain. ${ }^{7}$ To maintain the position of the neck in a normal level, the muscles will contract continuously. This posture compensation causes a change in the load on the cervical spine, as well as weakness in the deep neck flexor muscles. The problems that arise in the deep cervical flexor muscles will have an impact on the load, activation, and activity in maintaining stability in the cervical region so that in the end it will cause neck pain and neck disability. ${ }^{8}$ The prevalence of work-related neck pain will continue to increase if workers do $95 \%$ of the total working hours in one day which are carried out in a sitting position. ${ }^{9}$ When neck pain occurs, it is closely related to muscle problems. Muscles in the cervical area will experience a decrease in deep muscle muscle activity, increased 
co-contraction of the neck muscles, and muscle response. In conditions of work-related neck pain, it also results in muscle imbalance. ${ }^{10}$ Therefore, one of the trainings that can be applied to overcome the condition of work-related neck pain is deep cervical flexor with feedback.

\section{METHODS}

The method in this study using a literature review by conducting data studies related to deep cervical flexor training with feedback, neck pain, working. The literatures were acquired through electronic database such as Pedro, PubMed, and Google Scholar. The studies were included in this study if they are in English, described about the correlation working and neck pain, described about deep cervical flexor with feedback for pain and disability. The studies also used a research design such as randomized controlled trial, clinical trial, systemic review, experimental study, metaanalysis. The studies were excluded if they are not discussed about the training for neck pain. The initial search in 4 databases found a total of 36 articles. After the selection using inclusion and exclusion criteria obtained 28 articles.

\section{RESULTS}

Work related neck pain is one the most sizable health problem in everyday life especially when we work according to our profession which requires long term work in a day. The pain felt when experiencing this condition is caused by a lack of activation of the deep cervical flexors and reduced muscle endurance. ${ }^{5}$ Microtrauma and macrotrauma in the cervical region will affect the function of the motor control..$^{10}$ Literature studies show that providing deep cervical flexor training in conditions of neck pain can help reduce pain and can improve functional movement. ${ }^{5}$

This training is carried out in the supine position and put pressure sensor which was puffed to $20 \mathrm{mmHg}$ turned into positioned in the back of the neck of the patients and the dial which is linked to the strain sensor become given to the patient. The deep neck flexor activation turned into entered through performing cranio-cervical flexion, which increases the pressure inside the sensor, which is indicated with the aid of the motion of the dial. The patient changed into asked to increase the pressure via $2 \mathrm{mmHg}$ and preserve the pressure for 30 seconds. Repeat for ten times for three sets. ${ }^{11}$

Research conducted by Alghadir et al (2021) showed that providing deep cervical flexor training with feedback on neck pain conditions is effective in reducing pain and disability in the neck compared to conventional exercise. Giving this exercise results in a constant torque so that it will increase muscles that experience weakness and muscles that are less activated, reduce muscles that experience tightness which in turn will have an impact on increasing the performance of these muscles. ${ }^{5}$ Offering training courses can be more effective if the training period changes such as once a day then 4 days a week for 4 weeks. $^{7}$

The occurrence of neck pain problems can occur repeatedly if at work they do not pay attention to work posture, work environment, and exercises that can be done in between work. In addition, the problems will reappear if we do not pay attention to suitable training to overcome them. The exercises given focus on motor control, strengthening, and muscle endurance. ${ }^{10}$ Research by Ashfaq and Riaz (2021) states that addition of pressure biodfeedback in deep cervical flexor training indicates that it is more clinically powerful in lowering pain and increasing endurance muscle. ${ }^{8}$ This is also supported research by Karthi et al (2019) which states that given deep cervical flexor training with pressure feedback showed statistically and clinically significant results in decreased pain, range of motion from cervical, neck disability seen from NDI scores, and muscle endurance. ${ }^{11}$

The decrease in pain that happens can increase the functional motion of the neck in order that neck disability will lower. Elevated muscular endurance can assist inside the defense of neck stability. This training is an easy training to do and can be used as an intervention protocol in overcome the hassle of neck pain. ${ }^{8}$ Improvement in the condition of neck pain is done with the recovery of the muscles in terms of muscle function. ${ }^{11}$

\section{DISCUSSION}

Deep cervical flexor serves to maintain stabilization of movement in the neck region. If there are complaints of work related neck pain will cause harm to the muscle tissues. Destruction of these muscle tissues may additionally lead to insufficiency in its overload, activation, and bad assist on cervical systems ${ }^{5}$. When working with a static sitting position for a long term will exchange the posture of the neck. DCF training became more powerful to overcome neck pain. ${ }^{12}$

Research through Aziem and Draz (2016) by means of supplying deep cervical flexor training with pressure biodfeedback unit showed vast outcomes in decreasing the level of pain felt by means of research subjects. ${ }^{13}$ Giving this exercise can lowering the pain level related to modifications 
or enhancements in muscle functions in terms of muscle strength and endurance, that is because if you experience work related neck pain, there may be a lower in endurance and muscle strength of DCF. ${ }^{14}$ Adjusments in propioception and muscle spindle of brainstem neurons are another component that reason extensive change in pain intensity. ${ }^{15}$

There are several factors that make contributions to the occurrence of work related neck pain inclusive of duration whilst doing work, working posture in a static sitting role, a work environment that is not ergonomic. This thing can provoke the occurrence of muscle tension for a long term inside the area and changes in posture closer to the forward neck flexion. When there is a posture that has been adapted because of the routine performed when working will result in the neck stabilization muscle group experiencing greater emphasis to keep the posture in the appropriate position. ${ }^{16}$ Consequently, the provision of deep cervical flexor training with feedback has an influence on pain and disability in accordance with the results of research carried out on school teachers that showed significant adjusments in pain and disability reduction in comparison to those no longer given DCF training with feedback. ${ }^{17}$

DCF training with feedback is more efficient in dealing with problems in neck pain, especially pain and disability. ${ }^{18}$ The problem also is as a result of changes within the sensorymotor and neuromuscular. This exercise enables to lowering the work on the anterior scalene and sternocleidomastoideus muscular tissues and enhance the overall performance of the deep cervical flexor muscle. ${ }^{19}$ This method is indicated a relearning motor is sought to controlling the cervical muscles which will have an impact on the stability of the cervical region and maintain normal alignment. ${ }^{20}$

DCF training is proven on to be able to assist overcome problems in numerous kinds of work that reason neck pain. The training is powerful in lowering pain and improving useful movement of pilots who work with extended muscle contractions because of using flight helmet, posture during flight, and excessive amplitude vibrations. ${ }^{21} \mathrm{~A}$ deficit in deep cervical flexor muscle activation will seem on this condition. ${ }^{22}$ So that, the coordination of deep cervical flexor and superficial flexor muscles tissues is very important to take note of to get results that may offer impact and protection at some stage in training. ${ }^{23}$ Movement compensation will also occur because disturbances in a single area will growth muscle working in different areas. ${ }^{24}$

Lower in disability is likewise acquired by way of providing deep cervical flexor training with feedback. This lower may be seen from measurements the use of the neck disability index before training and after training for 7-8 weeks. ${ }^{25,26}$ Adjustments in disability are received due to a lower in pain that happens. When the pain felt has decreased there could be an increase in the function of the muscle groups which in flip will increase the mobility of the neck. ${ }^{27}$ Central and peripheral adaptations result from muscle activation due to this training. Changes also are proven via the mechanism of stimulation within the motor cortex and motor neurons that's associated with an growth in synaptic reactions while moving so that it will fortify the information link inside the synapse neurons in layer $\mathrm{V}$ and inside the horizontal cortical layer. ${ }^{28}$

\section{CONCLUSION}

Providing deep cervical flexor training with feedback is powerful in decreasing the level of pain and disability that happens when experiencing work related neck pain. The addition of feedback on deep cervical flecor training can serve activate the deep cervical flexor muscles that have a vital position in stabilization. Decreased pain received thru exercising because of muscle contraction at the same time as disability reduced because of pain lowering. In the future, it is hoped there will be research discusses exercise programs to prevent the reccurence work related neck pain.

\section{CONFLICT OF INTEREST}

The authors declare there is no conflict of interest in this study.

\section{FUNDING}

None

\section{REFERENCES}

1. Chilakwad NN, Rizvi SRA. Effectiveness of work hardening program in bankers having work-related chronic neck pain in bangalore. VIMS J Physical Th. 2019;1(2):79-85.

2. Khan U, Fasih M. Prevalence of work related neck pain among physiotherapists and its association with age and gender. Pak J Physiol. 2017;13(3):39-42.

3. Zang C, Zhou Y, Liu Y, Wu B. Efficacy of Stabilization Exercise for Neck Pain: A Narrative Review and MetaAnalysis of Randomized Controlled Studies. Physikalische Medizin, Rehabilitationsmedizin, Kurortmedizin. 2020;30(01):26-32.

4. Choi W. Effect of 4 Weeks of Cervical Deep Muscle Flexion Exercise on Headache and Sleep Disorder in Patients with Tension Headache and Forward Head Posture. Int J Environ Res Public Health. 2021;18(7):3410.

5. Alghadir AH, Iqbal ZA. Effect of Deep Cervical Flexor Muscle Training Using Pressure Biofeedback on Pain and Forward Head Posture in School Teachers with Neck Pain: 
An Observational Study. Biomed Res Int. 2021;2021.

6. Pawaria S, Sudan DS, Kalra S, Yadav J. Effectiveness of cervical stabilization exercises with feedback on respiratory status in chronic neck pain patients with forward head posture. Int J Physiother. 2019; 6(3).

7. Sikka I, Chawla C, Seth S, Alghadir AH, Khan M. Effects of deep cervical flexor training on forward head posture, neck pain, and functional status in adolescents using computer regularly. Biomed Research International. 2020.

8. Ashfaq R, Riaz H. Effect of pressure biofeedback training on deep cervical flexors endurance in patients with mechanical neck pain: a randomized controlled trial. Pak J Med Sci. 2021; 37(2):550-555.

9. Hallman DM, Gupta N, Heiden M, Mathiassen SE, Korshoj $\mathrm{M}$, Jorgensen $\mathrm{MB}$, Holtermann A. Is prolonged sitting at work associated with time course of neck-shoulder pain? A prospective study in danish blue-collar workers. BMJ Open. 2016;6.

10. Blomgren J, Strandell E, Jull G, Vikman I, Röijezon U. Effects of deep cervical flexor training on impaired physiological functions associated with chronic neck pain: a systematic review. BMC Musculoskelet Disord. 2018;19(1):1-17

11. Karthi M, Gopalswami A, Aseer A. Efficacy of endurance training on deep cervical flexor muscles using pressure feedback in mechanical neck pain. 2019.

12. Sikka I, Chawla C, Seth S, Alghadir AH, Khan M. Effects of deep cervical flexor training on forward head posture, neck pain, and functional status in adolescents using computer regularly. Biomed Res Int. 2020;2020.

13. Abdel-aziem AA, Draz AH. Efficacy of deep neck flexor exercise for neck pain: a randomized controlled study. Turkish Journal of Physical Medicine \& Rehabilitation/ Turkiye Fiziksel Tip ve Rehabilitasyon Dergisi. 2016;62(2).

14. Nezamuddin M, Khan SA, Hameed UA, Anwer S, Equebal A. Efficacy of pressure biofeedback guided deep cervical flexor training on forward head posture in visual display terminal operators. Indian Journal of Physiotherapy and Occupational Therapy. 2013;7(4):141.

15. Saleh MSM, Rehab NI, Sharaf MAF. Effect of deep cervical flexors training on neck proprioception, pain, muscle strength and dizziness in patients with cervical spondylosis: A randomized controlled trial. Phys Ther Rehabil. 2018;5(1):14

16. Raju AS, Apparao P, Swamy G, Chaturvadi P, Mounika RG. A comparative study on deep cervical flexors training and neck stabilization exercises in subjects with chronic neck pain. Indian Journal of Physiotherapy \& Occupational Therapy. 2019;13(2).

17. Iqbal ZA, Rajan R, Khan SA, Alghadir AH. Effect of deep cervical flexor muscles training using pressure biofeedback on pain and disability of school teachers with neck pain. Journal of physical therapy science. 2013;25(6):657-61.
18. Ashfaq R, Riaz H. Effect of Pressure biofeedback training on deep cervical flexors endurance in patients with mechanical neck pain: A randomized controlled trial. Pakistan Journal of Medical Sciences. 2021;37(2):550.

19. Blomgren J, Strandell E, Jull G, Vikman I, Röijezon U. Effects of deep cervical flexor training on impaired physiological functions associated with chronic neck pain: a systematic review. BMC Musculoskelet Disord. 2018;19(1):1-17.

20. Son KK, Cynn HS, Lee JH, Park DH, Kim BB. 2019. Effects of deep cervical flexor exercise with visual guide on muscle activity and craniovertebral angle in subjects with forward head posture. J Korean Soc Phys Med. 14(2): 53-61.

21. Amalina N, Setiawati E. Effectiveness of Deep Cervical Flexor (DCF) Exercise on Neck Functional Scores in Helicopter Crew with Mechanical Neck Pain. Surabaya Physical Medicine and Rehabilitation Journal. 2021;3(2):716.

22. Kang DY. Deep cervical flexor training with a pressure biofeedback unit is an effective method for maintaining neck mobility and muscular endurance in college students with forward head posture. Journal of physical therapy science. 2015;27(10):3207-10.

23. Jull G, Falla D, Vicenzino B, Hodges P. The effect of therapeutic exercise on activation of the deep cervical flexor muscles in people with chronic neck pain. Man Ther. 2009;14(6):696-701.

24. Kim E-Y, Kim K-J, Park H-R. Comparison of the effects of deep neck flexor strengthening exercises and Mackenzie neck exercises on head forward postures due to the use of smartphones. Indian Journal of Science and Technology. 2015;8(S7):569-75.

25. Bobos P, Billis E, Papanikolaou D-T, Koutsojannis C, MacDermid JC. Does deep cervical flexor muscle training affect pain pressure thresholds of myofascial trigger points in patients with chronic neck pain? A prospective randomized controlled trial. Rehabilitation research and practice. 2016;2016.

26. Kim JY, Kwag KI. Clinical effects of deep cervical flexor muscle activation in patients with chronic neck pain. Journal of physical therapy science. 2016;28(1):269-73.

27. Tsiringakis G, Dimitriadis Z, Triantafylloy E, McLean S. Motor control training of deep neck flexors with pressure biofeedback improves pain and disability in patients with neck pain: A systematic review and meta-analysis. Musculoskeletal Science and Practice. 2020:102220.

28. Falla D, O'Leary S, Farina D, Jull G. The change in deep cervical flexor activity after training is associated with the degree of pain reduction in patients with chronic neck pain. The Clinical journal of pain. 2012;28(7):628-34.

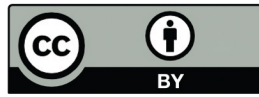

This work is licensed under a Creative Commons Attribution 